\author{
Nikoliuk 0. \\ Ph.D., Associate Professor \\ Department of Economic Theory and Economic of the Enterprise \\ Odessa State Agrarian University \\ Panteleimonovskaya str., 13, Odesa, Ukraine, 65012 \\ E-mail: alenavn11@gmail.com
}

\title{
FORMATION OF THE MODEL OF THE PUBLIC-PRIVATE PARTNERSHIPS AS AN INSTRUMENT FOR REGULATION OF THE SOCIO-ECONOMIC DEVELOPMENT OF AGRICULTURAL SECTOR
}

In the article the author's model of public-private partnership, which was developed based on its key principles and functions of the subjects of state-agricultural partnership in the agrarian sphere has been proposed. The factors that affect the efficiency of formation and development of the public-private partnerships play a key role in restoring agricultural production. The author states that the task of further reducing administrative barriers as one of the key factors in the development of agrarian production remains relevant. Today, from the side of the state, the formation and effective development of partnerships with agrarian business is determined by a number of contradictions and obstacles on the path to modernization of the agrarian sector, which must be eliminated with the help of the proposed models of public-private partnership.

Keywords: model of public-private partnership, state support, agribusiness, innovative development.

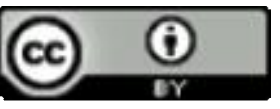

This work is licensed under a Creative Commons Attribution 4.0 International License http://creativecommons.org/licenses/by/4.0/

Statement of the problem and its connection with important scientific and practical tasks. Existing trends in the formation of approaches to the regulation of the socio-economic development of agricultural production are characterized by increasingly enhanced detailing of the conditions of interaction between the state and business in the implementation of the relevant strategy. From the framework regulation of the development of agricultural production, the state switched to the regulation of the socio-economic interests of the subjects of the agrarian market [8]. Such an approach contributes to increasing the effectiveness of state regulation instruments, and ensures the fulfilment of obligations assumed by private business. In its turn, the government targets to socioeconomic development of agricultural production stimulate innovative investment instruments require further improvement of the public-private partnership in the development of agricultural production. It should be noted that the task of further reducing administrative barriers as one of the key factors of agricultural production remains acute. Importantly, these tasks most efficiently occur within the direct interaction between the state and business.

The analysis of the latest publications on the problem. A detailed study and adaptation in the required amount of advanced world experience in the formulation and implementation of public-private partnership projects in the development of agrarian production, as well as the transfer of high technologies not possessed by domestic agricultural production, are of primary importance for the national economy, which is significantly inferior to innovation, advanced economies of the world. Such an opi- nion is given in the scientific works of famous scientists: P. T. Sabluka, M. Y. Malika, I. Y. Gryshova, O.M. Galytsky, S. S. Stoyanova-Koval, O.B. Naumova and others [1-10]. It should be noted that Ukraine does not have the necessary modern equipment for innovative modernization of agricultural production, so it is imported from abroad. In order for agricultural production in Ukraine to move away from the status of resource and raw material plots in the WTO, as well as the status of innovative industrial outsider, which encourages to raise the level of innovation activity in the agrarian production. That is why the urgency of the development of public-private partnership in the development of agrarian production is indisputable.

Forming of the aims of the research. To outline models of public-private partnership as an instrument for regulating the socio-economic development of agrarian production.

Giving an account of the main results and their substantiation. The current global trend is characterized by a reduction in budget support for science and education, while the share of private business is growing in the financing innovative directions for the implementation of scientific and technological progress, research and development ( $\mathrm{R} \& \mathrm{D})$. The experience of such countries as Israel, Finland, China and several other countries additionally emphasizes the fact that the integrated partnership of business and scientific and educational organizations by generating innovative ideas, developing new equipment, improving the production of high-tech technologies, improving the organization's infrastructure 
gives a powerful multiplier effect [3].

The basis for providing innovative activities in agricultural production should be partnership cooperation between the society, the state, agrarian business, and the educational and scientific sphere through the use of various forms of public-private partnership for solving the problems of socio-economic development of agrarian production and the national economy as a whole.

The use and additional attraction of private investment in the innovative agricultural development projects of agricultural production should be provided with the formation of favorable socio-economic conditions, taking into account the activity priority, the development of the legal framework of operation, the development of information and academic environments includes:

- the formation and legal consolidation of the provisions and other normative legal acts regulating the functioning of public-private partnership in the innovative activities of agrarian production;

- the creation and development of an innovative agrarian system: special economic zones, technoparks, technopolises, business incubators, technology platforms, technology transfer centers, venture funds, relevant economic zones, innovation support funds;

- the formation and implementation of new forms of public-private partnership;

- the activation of the system of state support of agrarian producers in the domestic and foreign markets [7].

Currently, the agrarian production of Ukraine expands the scope of the use of forms of public-private partnership, develops and improves the mechanisms for their implementation. Public-private partnership can be used as a special, but a complete replacement of the privatization programs conducted by the state when changing forms of management from state-owned enterprises to open joint-stock companies, using the potential of business, on the one hand, and maintaining the key functions of the state in new forms of state-owned forms of government-on the other hand.

From the side of the state the formation and effective development of the partnership with the agrarian business is determined by a number of contradictions and obstacles on the way to modernization of the agrarian sector:

1. The aggregate of subjects of agrarian production has a significant multiplicative effect with minimal funding and state support.

2. Domestic agrarian production is characterized by a significant level of conservatism and is inclined to conduct economic activity in the old way, without looking for new forms of management and, accordingly, new markets.

3. Current topical directions of development of agrarian production are highly risky, therefore the system of public-private partnership risks is an objective condition.

4. In the knowledge-intensive and capitalintensive areas of agrarian production, which are currently in a crisis and depression, but have a strong production base, it is expedient to attract additional investment resources in significant amounts.

5. Subjects of the agrarian production, provided keeping to an effective state agrarian policy, it is advisable to have precise guidelines for making decisions in the direction of business development [9].

In the framework of our research, we evaluated the factors that influence the effectiveness of the formation and development of public-private partnership, which play a key role in the neo-industrial restoration of agrarian production. At this time in the agricultural production there is a set of traditionally formed organizational and legal and organizational and economic forms of management with the direct participation of the state. There is also a public procurement system, where the state is directly involved as an equal partner in working with business structures. There are also concession, leasing, lease and other forms of cooperation with the agrarian business of the state [2].

One of the most important tasks of the present stage of diversification and socio-economic development of agrarian production in Ukraine is also the reformation of its organizational structure and infrastructure component. Such problems are a serious barrier to the transition to an innovative model for the development of the country's agrarian sector.

The main tasks of the functioning of the publicprivate partnership are to increase the competitiveness and efficiency of the functioning of agrarian production to the level of world leaders by combining the experience and resources of the state and business entities, implementation of projects for the modernization of production with minimal risks, costs for integration into the globalized world.

It should be noted that public-private partnership is a system of long-term or medium-term relations between the state and agrarian business for the production of the latest on behalf of the state of products.

In the framework of public-private partnership, it is advisable not only to take appropriate risks and invest in certain new projects in the agrarian sector, but also to form socio-economic conditions that should determine the development of the entire agricultural sector, to formulate an agrarian policy by which they should eliminate the existing shortcomings that impede the innovative development of agrarian production, as well as identify new stimulators for the implementation of innovation activities by agricultural producers.

Interaction of the state and agrarian business allows, on the one hand, to increase the efficiency of supporting the development of agrarian cultivation, on the other hand, to intensify private entrepreneurship and to create favorable conditions for its functioning. That is, the state and business become equal partners in their interest in the formation and development of innovative technologies focused on ensuring the competitiveness of agrarian production and the national economy. Therefore, there is the possibility of solving tasks related to technological modernization of production and food security in the country. 
Participants of the public-private partnership in agrarian production are the state represented by representatives of the government (state authorities, including the agencies regulating agricultural production, state enterprises and institutions, state commercial organizations), as well as subjects of the agrarian sector of the economy (commercial and non-profit organizations of different organizational and legal forms with participation in the units of the state or without its participation (jointstock companies), individuals).

If government bodies exercise a regulatory function, then business usually acts as an investor by taking part in the development of agrarian production. In addition to these general characteristics, each public-private partnership has its own competencies, expectations and style of work. Thanks to the successful implementation of public-private partnership projects, individual qualities and opportunities can be combined to achieve a common goal. Public-private partnership, focused on sustainable socio-economic development, provides innovative approaches to solving problems and achieving goals. The functions of public-private partnership in agrarian production are presented in table. 1

\section{Functions of public-private partnership in agrarian production*}

Table 1

\begin{tabular}{|c|l|}
\hline $\begin{array}{c}\text { Subjects } \\
\text { of partnership }\end{array}$ & \multicolumn{1}{c|}{ Executable functions } \\
\hline \multirow{5}{*}{ State } & $\begin{array}{l}\text { Development and approval of regulatory and legal principles of strategic development of market } \\
\text { economy, legislative definition of "rules of the game" of legal entities and individuals in the pro- } \\
\text { duction of agrarian products. } \\
\text { Promotion of effective in terms of national interest, integration of financial capital and subjects of } \\
\text { agrarian production. Assistance in finding sources of funding for programs related to the socio- } \\
\text { economic development of agrarian production. } \\
\text { Implementation of measures to optimize the production of agrarian products in order to provide } \\
\text { the population with qualitative and environmentally safe products, to improve the regulatory tools } \\
\text { at the macro level, to develop basic science, to implement state programs, to protect the environ- } \\
\text { ment, to develop social and domestic infrastructure, etc. }\end{array}$ \\
\hline $\begin{array}{c}\text { Agrarian } \\
\text { business }\end{array}$ & $\begin{array}{l}\text { Innovation activity is aimed at creating new types of products, innovative technologies. } \\
\text { Formation of necessary institutional conditions for cooperation of various agrarian producers with } \\
\text { innovative technologies. } \\
\text { Activity aimed at reducing the cost of production of agrarian products by optimizing costs. } \\
\text { Participation in the competition for obtaining a state order. Increasing the level of innovation and } \\
\text { investment activity in the market of agrarian products, including international ones. }\end{array}$ \\
\hline
\end{tabular}

* Systematized by the author on the basis of [3-9]

The relationship between the state and the subjects of agrarian production should be realized on the set

of principles (fig. 1).

\begin{tabular}{|l|l|l|l|l|l|l|l|l|l|l|}
\hline \multicolumn{7}{|c|}{ The principles of public-private partnership } & & \\
\hline proportionality & & transparency & & balance & & $\begin{array}{c}\text { providing } \\
\text { competition }\end{array}$ & $\begin{array}{c}\text { freedom of } \\
\text { contract }\end{array}$ & cooperation \\
\hline & & & & & & & & \\
\hline
\end{tabular}

Fig. 1. Principles of public-private partnership*

* developed by the author on the basis of [3-9]

The principle of proportionality implies that in the process of organizing and implementing publicprivate partnership projects, the public sector has the right to use or demand from the agrarian business only those actions that are: oriented towards the achievement of the goal of public-private partnership or the fulfillment of obligations undertaken by the business; necessary and related to the subject of public-private partnership; meet the strategic objectives of the public-private partnership, both in terms of both goals and results; above all will lead to restrictions or negatively reflected in the business sector. In the case of a unilateral breach by a state partner of obligations undertaken in the framework of a publicprivate partnership, the business partner is entitled to 
demand compensation for the damage, including unearned income.

The principle of transparency implies that, in the process of implementing public-private partnerships, the public sector must guarantee the objective choice of the private sector, while ensuring the maximum possible level of informing of all interested parties, taking into account the purpose, nature and significance of the subject of public-private partnership.

The principle of equilibrium - means tkat public-private partnership should be based on a balance of rights, responsibilities and benefits of business partnerships. The distribution of risks between the participants in the public-private partnership is carried out in accordance with the terms of the contract concluded between them, which specifies each type of risk and the share of risk that falls on each of the partners. In any case, a private partner, regardless of the form of public-private partnership, must cover at least part of the commercial risk. In the event of a business refusal to assume at least part of the commercial risk, regardless of its nature, relations between partners are not considered public-private.

The principle of ensuring competition - in the process of selecting a private partner, the public sector has no right to somehow restrict competition between stakeholders.

The principle of freedom of contract means that members of the state-affiliated partnership have the right to freely determine their rights and obligations with the help of the relevant agreement.

The principle of cooperation implies that the public sector should provide business assistance in obtaining permits and other documents stipulated by law or agreement, which promotes the development of publicprivate relations.

The principle of equality, impartiality and nondiscrimination presupposes that the state ensures an equal approach to all interested parties regarding any element or stage of the choice of a private partner. In any case, the criteria for choosing a private partner should be clear. The technical requirements should ensure equal access for interested parties and not create unjustified barriers or restrict competition [2].

The implementation of the proposed publicprivate model for the authorities will solve a set of tasks:

- enhance the rationality and efficiency of public investment resources which is extremely important in terms of their limitations;

- ensure the implementation of necessary innovation projects by increasing investment opportunities of the specific entities;

- will promote the development of specific industries in the corresponding territories.

As for the development and implementation of the model of public-private partnership, it is expedient to take into account the components of the potential of socio-economic development of agrarian production, which includes a set of necessary resources, as well as conditions and opportunities for their effective use.

Considering the potential of socio-economic development of agrarian production not only as a combinaand conducting a systematic monitoring of their effec- tion of relevant resources, but also in relation to the conditions of its use, and in agreement with existing positions regarding its structure [4], the following structural elements can be identified as the main structural components:

- financial component (a set of monetary resources and highly liquid financial assets, possible for use in socio-economic development of agrarian production);

- production component (a set of tangible and intangible assets accumulated by the private sector as a result of production activity);

- resource and raw material component (provision of necessary reserves of the most important types of resources that can be used in production activities);

- Infrastructure component (conditions that characterize the level of socio-economic development of industrial and social infrastructure in the territory where the production capacity is located);

- institutional component (provision of necessary institutions, conditions that characterize the level of development of institutions of financial and credit system, consulting, advisory and other organizations);

- personnel component (presence of highly skilled personnel, provision of the necessary conditions for personnel training in each region);

- intellectual component (level of education of the population, opportunities for improvement of qualification, level of development of R \& D, etc.);

- innovative component (level of implementation of achievements of scientific and technological progress and modernization of agrarian production).

From the above-mentioned components of the potential of socio-economic development, agrarian production is making efforts to accumulate financial, manufacturing, resource and raw materials and innovative components. In turn, the authorities take measures to support the infrastructure, institutional, personnel and intellectual components of the potential of socioeconomic development, providing conditions for the functioning of production, social infrastructure, the formation and development of human capital, etc. As a result of this interaction, the principles of public-private partnership are formed, the goal of which is the realization of a specific innovation project. In addition, the public-private partnership becomes relevant in terms of content and specificity, which contributes to the improvement of effectiveness.

From the point of view of the complex tasks of public-private partnership concerning socio-economic development of agrarian production, both for the business entities themselves, and for the authorities, its organizational design is important. That is the necessity of forming and realization of the mechanism of public-private partnership in ensuring of the socio-economic development of the agrarian production is becoming urgent (Fig. 2). The given mechanism of public-private partnership regulates organizational bases of interaction of the authorities and agrarian business in the formation of the policy of development of the agrarian production, as well as economic methods of generating goals, measures for improving the forms of public-private partnership tiveness. 


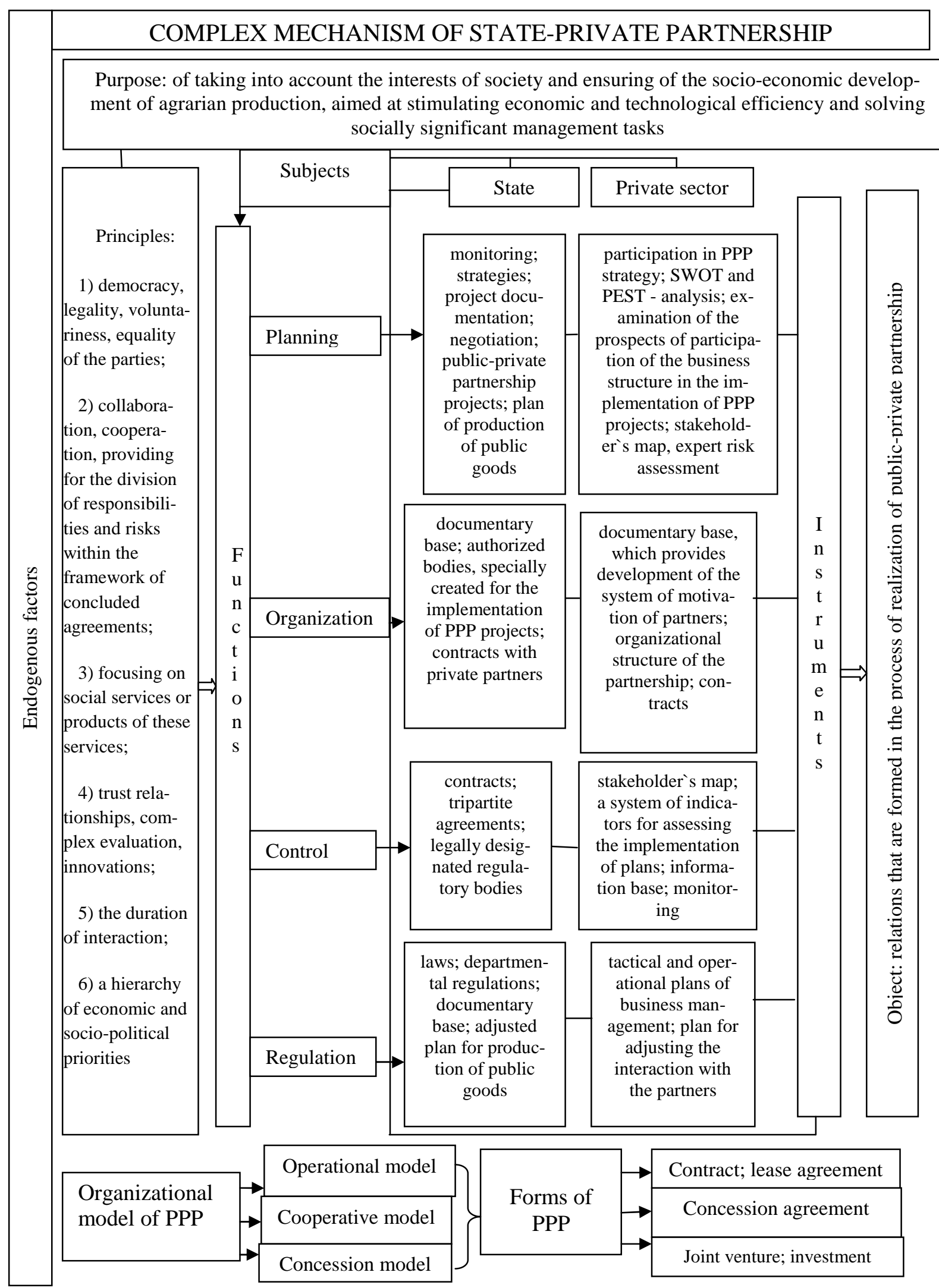

Tasks and results of the mechanism: formation of long-term relations of the state and the agrarian sector; improvement of the regulatory and methodological base; establishing a system of financing public-private partnership projects; intensification of an effective system of state regulation of the development of agrarian production;

forecasting and planning of ensuring the development of agrarian production and national economy

Fig. 2. Conceptual scheme of the mechanism of functioning of public-private partnership in the context of socio-economic development of agrarian production*

* developed by the author 
Conclusions and prospects of the further investigations. Almost all groups of public-private partnership instruments are aimed at increasing the competitiveness of the socio-economic system of the country and regions as territories favorable for the placement and development of agrarian production. The high competitive status of the socio-economic system of the state and regions forms the prerequisites for the development of agrarian production and provides an opportunity to attract investments in its leading industries.

In the course of the research the generalization of priority directions of the formation of a rational regulatory agrarian policy, which would promote the modernization and guaranteeing of the socio-economic development of agrarian production, has been carried out. Taking into account the results of the research, the identified prerequisites, established relationships, allocated functional subsystems, a model of socio-economic development of agrarian production under the conditions of the integration of the state and subjects of the agrarian production has been formed. In the strategic plan, the tasks of organisational and institutional imperatives for regulating the socio-economic development of agrarian production are the provision of a competitive, socially oriented, functioning agricultural production based on the principles of innovation.

The basis for providing innovation activity in the agricultural production should be partnership cooperation between societies, state, agrarian business, educational and scientific sphere through the use of various forms of public-private partnership for solving the tasks of socioeconomic development of agrarian production and the national economy as a whole. The main tasks of the functioning of the public-private partnership are to increase the competitiveness and efficiency of the functioning of the agrarian production to the level of world leaders by combining the experience and resources of the state and business entities, implementation of projects for the modernization of production with minimal risks, costs for integration into the globalized world.

Existing trends in the formation of approaches to the regulation of socio-economic development of agrarian production are characterized by increasingly enhanced detailing of the conditions of interaction between the state and business in the implementation of the relevant strategy. The necessity of forming and realization of the mechanism of public-private partnership for providing socio-economic development of agrarian production in Ukraine has been substantiated. The mechanism of public-private partnership regulates the organizational framework for the interaction of government agencies and agrarian businesses in forming the policy of developing agrarian production, as well as economic methods for generating goals, measures to improve the forms of public-private partnership, and conduct systematic monitoring of their effectiveness.

\section{References}

1. Prohrama rozvytku derzhavno-pryvatnoho partnerstva / Asotsiatsiia mist Ukrainy. (2018). Retrieved July 20, 2018, from http://2.auc.org.ua/page/programa-rozvitku-derzhavno-privatnogo-partnerstva

2. Ukraine. (2013). Kontseptsiia rozvytku derzhavno-pryvatnoho partnerstva v Ukraini na 2013-2018 roky: Rozporiadzhennia Kabinetu Ministriv Ukrainy vid 14.08.2013 № 739-r. (76th ed., pp. 1-291). Ofitsiinyi visnyk Ukrainy.

3. Sabluk, P. T. (2014). Zasady transformatsiinykh protsesiv v ahrarnii sferi. Intelekt XXI, (4), 25-36. Retrieved July 20, 2018, from http://nbuv.gov.ua/j-pdf/int_XXI_2014_4_5.pdf

4. Stoianova-Koval, S. S., \& Naumov, O. B. (2016). Mekhanizm derzhavno-pryvatnoho partnerstva yak instrument stabilizatsii investytsiinoho protsesu. Naukovi Zapysky Instytutu Zakonodavstva Verkhovnoi Rady Ukrainy, (6), 98-105.

5. Nikoliuk, O. V., \& Halytskyi, O. M. (2017). Metodolohiia instytutsionalizatsii derzhavnoho rehuliuvannia ahrarnoho vyrobnytstva. Ahrosvit, (13), 24-28.

6. Nikoliuk, O. V., \& Kravchuk, A. O. (2017). Aktyvizatsiia investytsiinykh protsesiv u konteksti podatkovoho navantazhennia natsionalnoi ekonomiky Ukrainy. Naukovi Zapysky Instytutu Zakonodavstva Verkhovnoi Rady Ukrainy, (4), 86-93.

7. Kosach, I. A. (2015). Derzhavno-pryvatne partnerstvo v konteksti systemno-synerhetychnoi paradyhmy. Problemy I Perspektyvy Ekonomiky Ta Upravlinnia, (2 (2)), 49-56.

8. Zahurskyi, O. M. (2012). Instytutsionalne zabezpechennia derzhavnoi pidtrymky ahrarnoho sektoru Ukrainy. Finansy Ukrainy, (8), 122-129.

9. Borshch, A. H. (2009). Biudzhetna pidtrymka ahrarnoho sektoru v umovakh transformatsiinykh protsesiv v ekonomitsi Ukrainy. Ekonomika APK, (2), 111-116. Retrieved July 21, 2018, from http://www.info-pressa.som/artisle552.html

10. Gryshova, I. Yu., \& Shestakovska, T. L. (2017). The asymmetry of the resource configuration and its destructive impact on the capitalization of agribusiness. The Scientific Papers of The Legislation Institute of The Verkhovna Rada of Ukraine, (2), 128-133.

11. Gryshova, I. Y., Shestakovska, T. L., \& Glushko, O. V. (2017). The economic measurement of convergence of institutional impact on the sustainability of development. Scientific Notes of The Institute of Legislation of The Verkhovna Rada of Ukraine, (4), 75-80. 


\author{
Николюк Е.B. \\ к.е.н., доцент \\ кафедра экономической теории и экономики предприятий \\ Одесский государственный аграрный университет \\ ул. Пеантелеймоновская, 13, г. Одесса, Украина, 65012 \\ E-mail: alenavn11@gmail.com
}

\title{
ФОРМИРОВАНИЕ МОДЕЛИ ГОСУДАРСТВЕННО-ЧАСТНОГО ПАРТНЕРСТВА В КАЧЕСТВЕ ИНСТРУМЕНТА РЕГУЛИРОВАНИЯ СОЦИАЛЬНО-ЭКОНОМИЧЕСКОГО РАЗВИТИЯ АГРАРНОГО СЕКТОРА
}

В статье предложены авторские модели государственно-частного партнерства, разработаны опираясь на его ключевые принципы и функции субъектов государственно-аграрного партнерства в аграрной сфере. Осуществлена оценка фракторов, влияющих на результативность формирования и развития государственно-частного партнерства и играют ключевую роль в восстановлении аграрного производства.Доказано, что использование и дополнительное привлечение частных инвестиций в инновационные проекты развития аграрного производства должны быть обеспечены формированием благоприятных социально-экономических условий с учетом приоритета деятельности, разработки нормативно-правовой базы функционирования, развития информационного и академического сред. Основой обеспечения инновационной деятельности в аграрном производстве должно быть партнерское сотрудничество общества, государства, аграрного бизнеса, образовательно-научной сферы путем применения различных форм государственно-частного партнерства для решения задач социально-экономического развития аграрного производства и национальной экономики в целом. Автор отмечает, что остается актуальной задача дальнейшего снижения административных барьеров как одного из ключевых факторов развития аграрного производства. Сегодня со стороны государства фрормирования и эффективное развитие партнерских отношений с аграрным бизнесом определяется рядом противоречий и препятствий на пути к модернизации аграрного сектора, которые должны быть устранены с помощью предложенных моделей государственно-частного партнерства.

Ключевые слова: модель государственно-частного партнерства, государственная поддержка, агробизнес, инновационное развитие.

\section{Ніколюк О.В.}

к.е.н., доцент

кафедра економічної теорії і економіки підприємства

Одеський державний аграрний університетами

вул. Пантелеймонівська, 13, м. Одеса, Україна, 65012

E-mail: alenavn11@gmail.com

\section{ФОРМУВАННЯ МОДЕЛІ ДЕРЖАВНО-ПРИВАТНОГО ПАРТНЕРСТВА ЯК ІНСТРУМЕНТУ РЕГУЛЮВАННЯ СОЦІАЛЬНО- ЕКОНОМІЧНОГО РОЗВИТКУ АГРАРНОГО СЕКТОРУ}

В статті запропоновані авторські моделі державно-приватного партнерства, що розроблено спираючись на його ключові принципи та функції суб'єктів державно-аграрного партнерства в аграрній сфрері. Здійснено оцінку факторів, які впливають на результативність формування та розвитку державно-приватного партнерства та відіграють ключову роль у відновленні аграрного виробництва. Доведено, що використання й додаткове залучення приватних інвестицій в інноваційні проекти розвитку аграрного виробництва повинні бути забезпечені формуванням сприятливих соціально-економічних умов 3 урахуванням пріоритету діяльності, розробки нормативно-правової бази функціонування, розвитку інформаційного й академічного середовищ. Базисом забезпечення інноваційної діяльності у аграрному виробництві повинно бути партнерське співробітництво суспільства, держави, аграрного бізнесу, освітньо-наукової сфери через застосування різних форм державно-приватного партнерства для вирішення завдань соціально-економічного розвитку аграрного виробництва й національної економіки в цілому. Автор зауважує, що залишається актуальним завдання подальшого зниження адміністративних бар'єрів як одного з ключових факторів розвитку аграрного виробництва. Сьогодні зі сторони держави формування й ефеектиний розвиток партнерських відносин з аграрним бізнесом визначається рядом суперечностей та перешкод на шляху до модернізації аграрного сектору, які повинні бути усунені за допомогою запропонованих моделей державно-приватного партнерства.

Ключові слова: модель державно-приватного партнерства, державна підтримка, агробізнес, інноваційний розвиток. 


\section{Література}

1. Програма розвитку державно-приватного партнерства / Асоціація міст України: веб-сайт. URL: http://www.auc.org.ua/page/programa-rozvitku-derzhavno-privatnogo-partnerstva (дата звернення: 20.07.2018).

2. Концепція розвитку державно-приватного партнерства в Україні на 2013-2018 роки: Розпорядження Кабінету Міністрів України від 14.08.2013 № 739-р. // Офіційний вісник України. 2013. № 76. Ст. 2831. С. 291.

3. Саблук П.Т. Засади трансформаційних процесів в аграрній сфері. Інтелект XXI. 2014. № 4. С. 25-36. URL: http://nbuv.gov.ua/j-pdf/int_XXI_2014_4_5.pdf (дата звернення: 20.07.2018).

4. Стоянова-Коваль С.С., Наумов О.Б. Механізм державно-приватного партнерства як інструмент стабілізації інвестиційного процесу // Наукові записки Інституту законодавства Верховної Ради України. 2016. № 6. C. $98-105$.

5. Ніколюк О.В., Галицький О.М. Методологія інституціоналізації державного регулювання аграрного виробництва // Агросвіт. 2017. №13. С. 24-28.

6. Ніколюк О.В., Кравчук А.О. Активізація інвестиційних процесів у контексті податкового навантаження національної економіки України // Наукові записки Інституту законодавства Верховної Ради України. 2017. № 4. C. 86-93.

7. Косач I. А. Державно-приватне партнерство в контексті системно-синергетичної парадигми // Проблеми і перспективи економіки та управління: наук. журн. 2015. № 2 (2). С. 49-56.

8. Загурський О.М. Інституціональне забезпечення державної підтримки аграрного сектору України // Фінанси України. 2012. № 8. С. 122-129.

9. Борщ А.Г. Бюджетна підтримка аграрного сектору в умовах трансформаційних процесів в економіці України // Економіка АПК. 2009. № 2. С. 111-116. URL: http://www.info-pressa.com/article-552.html (дата 3вернення: 21.07.2018).

10. Gryshova I. Yu., Shestakovska T. L. The asymmetry of the resource configuration and its destructive impact on the capitalization of agribusiness. The Scientific Papers of the Legislation Institute of the Verkhovna Rada of Ukraine. 2017. №2. P.128-133.

11. Gryshova I. Yu., Shestakovska T. L., Glushko O. V. The economic measurement of convergence of institutional impact on the sustainability of development. Scientific notes of the Institute of Legislation of the Verkhovna Rada of Ukraine. 2017. №4. P.75-80.

Стаття надійшла 25.07.2018

Стаття прийнята до друку 8.08.2018

Доступно в мережі Internet 17.10.2018

Цитування згідно ДСТУ 8302:2015

Ніколюк О.В. Формування моделі державно-приватного партнерства як інструменту регулювання соціальноекономічного розвитку аграрного сектору // Економіка харчової промисловості. 2018. Т. 10, Вип. 3. С. 13-20; doi: 10.15673/fie.v10i3.1056

Cite as APA style citation

Nikoliuk, O. (2018). Formation of the model of the public-private partnerships as an instrument for regulation of the socioeconomic development of agricultural sector. Food Industry Economics, 10(3), 13-20; doi: 10.15673/fie.v10i3.1056 